\title{
An Evaluation of the Be Bear Aware Program at Grand Teton National PARK
}

\author{
NANETTE M. NELSON $\downarrow$ PATRICIA A. TAYLOR $\downarrow$ TYLER HOPKINS $\downarrow$ AMY RIESER \\ WYOMING SURVEY \& ANALYSIS CENTER $\uparrow$ UNIVERSITY OF WYOMING $\uparrow$ LARAMIE
}

\begin{abstract}
$\uparrow \quad$ Abstract
Two years after initiating the Be Bear Aware program, management at Grand Teton National Park (GRTE) engaged the Wyoming Survey \& Analysis Center (WYSAC) at the University of Wyoming to complete an evaluation of the public information and education component of the program. The focus of this program is to change visitor behavior (e.g., engaging in proper food storage, responsible recreation) through education. The desired outcome is to minimize the probability of human-bear encounters and the potential for conflict in park with thriving black bear and grizzly bear populations.
\end{abstract}

To evaluate the efficacy of the program, WYSAC researchers collected information on the visibility of Be Bear Award signs, access to and use of Be Bear Aware information, visitor knowledge of GRTE's food storage policy, and recreating safely while in bear country. WYSAC researchers then developed a questionnaire and interviewed a randomized stratified sample of 634 park visitors during the summer of 2010. The results of this study should help park managers identify aspects of the Be Bear Aware program that are working and those that can be improved upon.

\section{$\downarrow \quad$ INTRODUCTION}

The National Park Service management program for bears in GRTE is to sustain "free ranging, naturally regulated populations" of bears throughout the Park including the John D. Rockefeller, Jr. Memorial Parkway (GRTE, 2007). However, nearly 4 million visitors recreate in GRTE every year, which produces a high probability of bear-human encounters and the potential for conflict.

In 2007, GRTE recorded 210 bear-human confrontations and 56 bear-human conflicts. Confrontation are defined by the park as "incidents where bears approach or follow people, charge or otherwise act aggressively toward people, enter frontcountry developments, or enter occupied backcountry campsites without inflicting human injury." Bearhuman conflicts are defined by the park as "incidents where bears damage property, obtain human foods, or injure people" (GRTE 2007, p1). Bears which become aggressively conditioned to human food, may be destroyed, and GRTE did destroy a record number of 4 black bears during 2007 (GRTE, 2007). The park, therefore, endeavored to develop and implement a wildlife management strategy that balanced the needs of bears with visitor enjoyment, education, and appreciation of the park.

In 2007 Grand Teton National Park (GRTE) initiated the Be Bear Aware program in an effort to reduce bear-human encounters and potential conflicts within the park. Two years later park management engaged the Wyoming Survey \& Analysis Center (WYSAC) at the University of Wyoming to complete an evaluation of the public information and education component of the program. This particular aspect of the program focused on education as a means of changing visitor behavior (e.g., engaging in proper food storage, what to do if you encounter a bear).

Discussions with park managers resulted in the following research questions which framed the study: 
- Are park visitors seeing the Be Bear Aware information and, if so, where do they see it?

- Do park visitors comprehend the information and do they act on it?

- What information from Be Bear Aware (or other information) results in visitors engaging in proper behavior?

- Does the Be Bear Aware information transcend the campground?

To evaluate whether the information disseminated as part of the Be Bear Aware program is in fact reaching park visitors, and is effective, WYSAC conducted a face-to-face intercept survey of a sample of campground visitors and picnickers during the summer months of 2010. This report discusses and summarizes the results of this survey.

\section{$\uparrow$ STUDY BACKGROUND}

GRTE managers initiated the Be Bear Aware program at the start of the 2007 season. The new program is an integrated strategy consisting of five elements: 1) public information and education; 2) removal of human food sources; 3 ) enforcement of food storage regulations; 4) management and control of problem bears; and 5) research. As part of the public information and education component, the park updated its bear-related message. This included adoption of a universal theme "Be Bear Aware," designing new graphics to improve message visibility, wider display of the bear warning signs, and increasing visitor outreach efforts at the park's entrance and high-use areas. The current message emphasizes food storage, outlining a strict set of rules about what items should be stored (e.g., food, coolers, water bottles, utensils, etc.) and how to store items properly (i.e., in a bear box or a closed, locked vehicle with windows closed).

The park also developed several guidelines on how to safely and responsibly recreate in bear country. These guidelines have been widely disseminated throughout the park including a full page in the Teewinot, the park's newspaper. The newspaper, handed to all park arrivals, gives information on food storage, behavior during a bear encounter, differences between black and brown bear, and safety on trails.

Despite these efforts park employees are still observing noncompliance with GRTE's food storage policy, resulting in more "problem bears," and requiring the allocation of limited resources toward managing problem bears. When bears actively seek

1.We discovered during the course of the study that park visitors arriving from Yellowstone do not always receive the Be Bear Aware Program message.

sources of human food, property damage and injuries to humans may result. In the interest of protecting park visitors and preserving the park's bears, GRTE managers sought a formal evaluation and education portion of the Be Bear Aware program.

During the summer of 2009 WYSAC researchers, in collaboration with park managers, developed and tested the questionnaire that was used to collect the data for the evaluation of the Be Bear Aware program, using both focus groups and a pretest procedure. Questionnaire specifics were reported on previously in Nelson, Taylor \& Rieser (2009).

\section{METHODS}

\section{Sample Design}

As our study was limited to front country users, we confined our survey administration to campgrounds and picnic areas. Therefore, the study population did not target backcountry campers or day visitors who did not make use of the picnic areas or front country campgrounds. Furthermore, because park managers were interested in message penetration, all park visitors to campgrounds and picnic areas were in the population universe to be sampled, whether they had food with them or not.

Our sample design was based on a probability sampling approach. Probability based sampling as opposed to convenience sampling allows us to generalize our results to the population, in our case to all campers and picnickers visiting the park during the summer of 2010 . We selected all campsites and picnic sites within the park as our sampling frame. Because the number of campsites and picnic areas are fixed, this approach allowed us to draw our sample from a known number of sampling units whereas the number of visitors to the park over a specified time period is variable.

Since our target was 625 completed surveys, and approximately $10 \%$ of all sites were picnic sites, we estimated completing interviews from 63 picnic sites (Nelson et al., 2009). The remaining 562 surveys were completed at campgrounds at rates proportional to the size of the campground and occupancy rate (Table 1 for target numbers of completions by campground). The sampling effort at 
Colter Bay and Flagg Ranch campgrounds was further subdivided based on type of overnight camping (e.g. group site vs. single tent site).

\section{Data Collection, Response Rates \& Margins of Error}

The collection times for the campgrounds were separated into a morning shift (8:30 am to 10 am) and an evening shift from (5pm to $8 \mathrm{pm})$ to coincide with the time of day that campers would mostly likely be at their campsites (i.e., meal times). The middle hours of the day were set aside to sample picnic areas.

Table 1. Sampling Effort by Campground

\begin{tabular}{|c|c|c|c|c|c|}
\hline 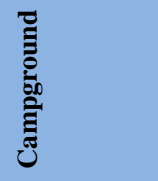 & $\begin{array}{l}\frac{y}{0} \\
\frac{0}{0} \\
\frac{0}{0} \\
\#\end{array}$ & 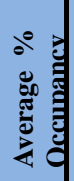 & 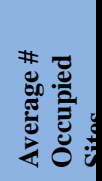 & 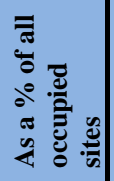 & 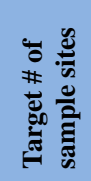 \\
\hline $\begin{array}{l}\text { Colter Bay } \\
\text { campgroun } \\
\text { d }\end{array}$ & 371 & $\begin{array}{c}10 \\
0\end{array}$ & 371 & 30.1 & 169 \\
\hline $\begin{array}{l}\text { Colter Bay } \\
\text { RV park }\end{array}$ & 112 & $\begin{array}{c}10 \\
0\end{array}$ & 112 & 9.1 & 51 \\
\hline $\begin{array}{l}\text { Colter Bay } \\
\text { Tent } \\
\text { Village }\end{array}$ & 66 & $\begin{array}{c}10 \\
0\end{array}$ & 66 & 5.3 & 30 \\
\hline $\begin{array}{l}\text { Flagg } \\
\text { Ranch - } \\
\text { tent only }\end{array}$ & 74 & 98 & 73 & 5.9 & 33 \\
\hline $\begin{array}{l}\text { Flagg } \\
\text { Ranch - } \\
\text { RV sites }\end{array}$ & 97 & 98 & 95 & 7.7 & 43 \\
\hline $\begin{array}{l}\text { Grassy } \\
\text { Meadows }\end{array}$ & 10 & 50 & 5 & 0.4 & 2 \\
\hline Gros Ventre & 324 & 96 & 311 & 25.2 & 142 \\
\hline Jenny Lake & 61 & $\begin{array}{c}10 \\
0\end{array}$ & 61 & 4.9 & 28 \\
\hline $\begin{array}{l}\text { Lizard } \\
\text { Creek }\end{array}$ & 63 & 92 & 58 & 4.7 & 26 \\
\hline $\begin{array}{l}\text { Signal } \\
\text { Mountain }\end{array}$ & 86 & 96 & 83 & 6.7 & 38 \\
\hline Total & $\begin{array}{c}126 \\
4\end{array}$ & & 1234 & 100 & 562 \\
\hline
\end{tabular}

Potential survey respondents at campgrounds, or more accurately their campsites, were selected using systematic sampling. The systematic method started at a numbered camp site randomly selected, with a randomly selected $\mathrm{k}^{\text {th }}$ number so as to choose every $\mathrm{k}^{\text {th }}$ unit thereafter to sample. We used a random number generator to select a new, random start point for each survey shift at each campground. At the beginning of the study we replaced $\mathrm{k}$ every day starting with $\mathrm{k}=3$, increasing $\mathrm{k}$ by one every day for the next two days (until $k=5$ ), and then beginning over again at $\mathrm{k}=3$. During the last two weeks of the study $\mathrm{k}$ was held constant at $\mathrm{k}=2$ to ensure we met our target completions. If a campsite was occupied but the campers were not available (i.e., no one around) the site visit was logged as incomplete and a second attempt was made to intercept the potential respondents during the next survey shift. After the second attempt if a camper was not intercepted the site was dropped from the sample. If a campsite was not occupied but was part of the sample then a replacement was used by locating the next available (i.e., occupied) site. If no replacement was located before the next campsite in the sample, the site was dropped from the sample.

We used a modified version of systematic sampling for the picnic areas because unlike the campgrounds, the picnic tables had not been systematically mapped, the tables lack numbering, and not all picnickers used tables. Upon arrival at a picnic area we mentally divided the area into sections, sampling one table or group from each section. If time allowed, the sections were canvassed a second time obtaining a unique sample of potential respondents from the first round. Visitors at picnic areas were not pre-screened to determine the purpose of their trip before being selected to complete the survey. Therefore, the resulting sample of picnickers included some individuals who were camping in GRTE or Yellowstone National Park.

To assess whether park visitors were seeing the Be Bear Aware signage our survey included a question that involved the field researcher showing a series of signs and asking respondents to recall if they had seen each sign, where they saw the sign, and how many times (see Questionaire at the end of this report Questions 20 a-f in Appendix A). After interviewing multiple park visitors who had been in the park for more than a few days we realized the last part of the question ("How many times have you seen this sign?") was not producing reliable results among respondents or the field researchers. Therefore we decided to forgo collecting this information knowing that in our analysis we could use length of stay in the park as a proxy measure for this variable.

Between July 19, 2010 and August 14, 2010, a combination of 649 campers and picnickers were approached and their participation requested to complete the Be Bear Aware survey. Of those asked to participate only 23 refused resulting in a cooperation rate of $96.5 \%$. The completed number of surveys was 634, of which 67 were picnickers and 567 were campers. Random samples of 634 yield margins of error of about \pm 4.0 percentage points with $95 \%$ confidence. 


\section{Data Compilation and Analysis}

The data were exported to the Statistical Package for the Social Sciences (SPSS), version 18.0. Data analysts cleaned the data and recoded some of the variables to enable ease of presentation. The detailed results of the survey findings including raw frequency counts and percentage distributions of responses to all questions on the survey can be found in Nelson, Taylor, Hopkins \& Rieser (2011).

At the park's request we sampled both picnickers and campers for this study. Our sample of picnickers was comprised of visitors to GRTE that were on a day trip from Yellowstone National Park, camping in GRTE (but picnicking at a picnic site when they were intercepted for the survey), visiting from elsewhere, or that live in the area. The consequence of the different visitor types in the sample of picnickers is that they have had dissimilar exposure to Be Bear Aware information. Therefore, we chose to analyze the picnickers and campers separately.

Table 2. Number of Prior Visits to GRTE in the Last 24 Months

\begin{tabular}{|l|c|c|c|}
\hline $\begin{array}{l}\text { Number of } \\
\text { Visits* }\end{array}$ & Campers & Picnickers & All \\
\hline First visit ever & $48.3 \%$ & $35.8 \%$ & $47.0 \%$ \\
\hline 1 & $28.6 \%$ & $26.9 \%$ & $53.8 \%$ \\
\hline 2 & $15.1 \%$ & $17.9 \%$ & $29.2 \%$ \\
\hline $3-5$ & $5.2 \%$ & $4.5 \%$ & $9.8 \%$ \\
\hline $6-10$ & $1.4 \%$ & $4.5 \%$ & $3.3 \%$ \\
\hline More than 10 & $1.1 \%$ & $4.5 \%$ & $3.9 \%$ \\
\hline
\end{tabular}

We tested observed differences between campers and picnickers for statistical significance using the overall Pearson's chi-square test. For all instances in which the tests were statistically significant $(p<0.05)$ there is a notation in the respective table.

To identify subgroups of visitors we used latent class analysis (LCA). LCA separates cases (i.e., campers) into groups such that members of each group are similar to one another while maximizing the distinctions between the groups. The term latent refers to the fact that the groups cannot be directly observed, but instead are derived from a set of observed, categorical data. For example, it can be used to identify "strong" bear aware campers and "weak" bear aware campers. It can also be used to estimate the size of these groups. The analysis was performed with the LCA program Latent GOLD, Version 4.5. The analysis was performed on the camper group only due to insufficient variability in the data collected on picnickers.

\section{Trip Characteristics \& Demographics}

Just under half (48\%) of campers sampled indicated this was their first visit to GRTE compared to $36 \%$ of picnickers sampled (Table 2). Of those who had previously visited the park, campers and picnickers were similar in their park visitation patterns up through five visits in the last 24 months. The percentage of picnickers who had visited the park six or more times was higher than that of campers. An overall test of differences between campers and picnickers for number of visits to the park was significant $(p<0.001)$ indicating the two groups exhibit different visitation patterns. Summaries of overnight accommodations and expected length of stay in the park are presented in Tables 3 and 4, respectively. Both types of overnight accommodations and expected length of stay showed significant differences between campers and picnickers.

Table 3. Overnight Accommodations Used During Visit ${ }^{1}$

\begin{tabular}{|l|c|c|c|}
\hline Facility Type & Campers & Picnickers & All \\
\hline Lodge* & $1.4 \%$ & $9.0 \%$ & $2.2 \%$ \\
\hline RV / Van* & $43.6 \%$ & $9.0 \%$ & $39.9 \%$ \\
\hline Pop-up Trailer & $10.9 \%$ & $6.0 \%$ & $10.4 \%$ \\
\hline Tent Village & $5.7 \%$ & $1.5 \%$ & $5.3 \%$ \\
\hline Our own tent* & $43.1 \%$ & $10.4 \%$ & $39.6 \%$ \\
\hline $\begin{array}{l}\text { Camping under } \\
\text { the stars }\end{array}$ & $0.9 \%$ & $0.0 \%$ & $0.9 \%$ \\
\hline $\begin{array}{l}\text { Staying outside } \\
\text { the park }\end{array}$ & $0.9 \%$ & $37.3 \%$ & $4.8 \%$ \\
\hline Live in the area & $0.4 \%$ & $16.4 \%$ & $2.1 \%$ \\
\hline $\begin{array}{l}\text { Other/Don't } \\
\text { know* }\end{array}$ & $2.0 \%$ & $19.4 \%$ & $3.8 \%$ \\
\hline
\end{tabular}

Total percentage is greater than 100 because visitors could select more than one answer choice.

${ }^{*}$ Chi-square test: $p<.001$

Table 4. Expected Length of Stay in the Park

\begin{tabular}{|l|c|c|c|}
\hline $\begin{array}{l}\text { Length of } \\
\text { Stay* }\end{array}$ & Campers & Picnickers & All \\
\hline $\begin{array}{l}\text { Less than } \\
12 \text { hours }\end{array}$ & $0.0 \%$ & $35.8 \%$ & $3.8 \%$ \\
\hline 1 day & $4.7 \%$ & $17.9 \%$ & $6.1 \%$ \\
\hline 2 days & $16.3 \%$ & $10.4 \%$ & $15.7 \%$ \\
\hline 3 days & $19.7 \%$ & $6.0 \%$ & $18.2 \%$ \\
\hline 4 days & $17.2 \%$ & $11.9 \%$ & $16.6 \%$ \\
\hline $5-7$ days & $26.4 \%$ & $16.5 \%$ & $25.4 \%$ \\
\hline $\begin{array}{l}\text { More than 7 } \\
\text { days }\end{array}$ & $15.7 \%$ & $1.5 \%$ & $14.2 \%$ \\
\hline
\end{tabular}

${ }^{*}$ Chi-square test: $p<.001$

The demographic composition of park visitors who completed the survey is presented in Table 5. The data presented in Table 5 represent the 
primary individual selected to complete the survey. There were slightly more male respondents in the camper group $(60 \%)$ compared to the picnickers $(55 \%)$. Both groups were older than the general population with just over three-quarters of those intercepted being 41 years of age or older $(77 \%)$. Likewise both groups were highly educated with over two-thirds indicating completion of a secondary or post-secondary education $(67 \%)$. More campers interviewed had children among their party (62\%) compared to picnickers interviewed (54\%).

Table 5. Demographic Summary of Park Visitor Sample

\begin{tabular}{|c|c|c|c|}
\hline Demographic & Campers & Picnickers & All \\
\hline \multicolumn{4}{|l|}{ Gender } \\
\hline Male & $60.8 \%$ & $55.2 \%$ & $60.2 \%$ \\
\hline Female & $39.2 \%$ & $44.8 \%$ & $39.8 \%$ \\
\hline \multicolumn{4}{|l|}{$\overline{\text { Age }}$} \\
\hline $18-25$ & $5.2 \%$ & $7.5 \%$ & $5.4 \%$ \\
\hline $26-40$ & $18.2 \%$ & $14.9 \%$ & $17.9 \%$ \\
\hline $41-55$ & $39.2 \%$ & $46.3 \%$ & $39.9 \%$ \\
\hline $56-70$ & $32.7 \%$ & $26.9 \%$ & $32.1 \%$ \\
\hline 70 and higher & $4.7 \%$ & $4.5 \%$ & $4.6 \%$ \\
\hline \multicolumn{4}{|l|}{ Education } \\
\hline Some high school & $0.9 \%$ & $1.5 \%$ & $1.0 \%$ \\
\hline $\begin{array}{l}\text { High school } \\
\text { graduate or GED }\end{array}$ & $8.8 \%$ & $7.5 \%$ & $8.6 \%$ \\
\hline $\begin{array}{l}\text { Some college or } \\
\text { technical school }\end{array}$ & $24.0 \%$ & $19.4 \%$ & $23.5 \%$ \\
\hline Bachelor's degree & $35.1 \%$ & $37.3 \%$ & $35.3 \%$ \\
\hline Graduate degree & $31.3 \%$ & $34.3 \%$ & $31.6 \%$ \\
\hline \multicolumn{4}{|l|}{$\begin{array}{l}\text { Group } \\
\text { Composition }\end{array}$} \\
\hline Children present & $62.0 \%$ & $53.8 \%$ & $61.1 \%$ \\
\hline $\begin{array}{l}\text { No children } \\
\text { present }\end{array}$ & $38.0 \%$ & $46.2 \%$ & $38.9 \%$ \\
\hline
\end{tabular}

\section{$\downarrow$ KEY FINDINGS}

\section{Visibility of \& Access to Be Bear Aware Information}

We determined the extent to which park visitors were seeing the Be Bear Aware message by showing survey respondents a series of six signs the park uses as part of their public information and education effort and asking if the respondent remembered seeing each sign (Question 20 a-f in Appendix A). Nearly $90 \%$ of all campers surveyed remembered seeing the yellow placard stapled to every picnic table in the park (Table 6). Slightly fewer campers $(86 \%)$ recalled seeing the diamondshaped yellow sign with a large bear paw print asking visitors to "Be Bear Aware." For both signs, significantly fewer picnickers recalled seeing them (79\% and $72 \%$, respectively). The brown roadside sign indicating "Food Storage Required" was remembered by $76 \%$ of respondents. Only two-thirds of our sample of campers recalled seeing the "You can help save a bear!" sign posted in bathrooms (usually on mirrors) compared to $57 \%$ of picnickers. The two signs with the lowest percentage recall "Warning - Bear Frequenting Area" and "Danger Trail Closed" - are limited in their use and not all visitors would necessarily encounter them while in the park. These signs tend to be at trailheads, more than on picnic tables. Thus we would expect that these two signs would not have nearly the same visibility as the other four signs and indeed that was the result.

Table 6. Percent Saying "Yes" to Seeing Be Bear Aware Signs

\begin{tabular}{|c|c|c|c|c|c|}
\hline \multirow[b]{2}{*}{ 矛送 } & \multirow[b]{2}{*}{ 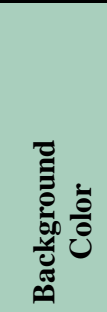 } & \multirow[b]{2}{*}{ 预 } & \multicolumn{3}{|c|}{$\begin{array}{l}\text { Percent Saying } \\
\text { "Yes" to Seeing } \\
\text { Sign }\end{array}$} \\
\hline & & & 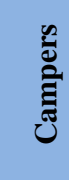 & 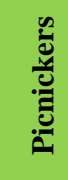 & ₹ \\
\hline $\begin{array}{l}\text { Be Bear } \\
\text { Aware! } \\
\text { Food \& } \\
\text { Odors } \\
\text { Attract } \\
\text { Bears* }\end{array}$ & Yellow & $\begin{array}{l}\text { Picnic } \\
\text { tables }\end{array}$ & 89.8 & 79.1 & 88.6 \\
\hline $\begin{array}{l}\text { Be Bear } \\
\text { Aware - It } \\
\text { all smells to } \\
\text { a bear - } \\
\text { Lock it up!* }\end{array}$ & Yellow & $\begin{array}{c}\text { Trash } \\
\text { cans \& } \\
\text { bear } \\
\text { boxes }\end{array}$ & 86.2 & 71.6 & 84.6 \\
\hline $\begin{array}{l}\text { Be Bear } \\
\text { Aware :Food } \\
\text { Storage } \\
\text { Required } \\
\end{array}$ & Brown & Roads & 76.1 & 76.1 & 76.1 \\
\hline $\begin{array}{l}\text { You can } \\
\text { help save a } \\
\text { Bear! }\end{array}$ & White & $\begin{array}{c}\text { Bathro } \\
\text { oms }\end{array}$ & 66.2 & 56.7 & 65.2 \\
\hline $\begin{array}{l}\text { Warning } \\
\text { Bear } \\
\text { Frequenting } \\
\text { Area }\end{array}$ & $\begin{array}{l}\text { Yellow } \\
\text { or } \\
\text { White }\end{array}$ & $\begin{array}{l}\text { Campg } \\
\text { rounds } \\
\& \\
\text { picnic } \\
\text { areas } \\
\end{array}$ & 34.2 & 37.3 & 34.5 \\
\hline $\begin{array}{l}\text { Danger } \\
\text { Closed }\end{array}$ & White & $\begin{array}{c}\text { Closed } \\
\text { hiking } \\
\text { trails }\end{array}$ & 10.8 & 13.6 & 11.1 \\
\hline
\end{tabular}

Information on proper food storage and recreating safely while in bear country is available on the park's website, at the southern entrance to the 
park, at campground registration, and through conversations with park personnel. We evaluated the extent to which visitors were accessing these sources for information and, in the first three cases, whether they had read the information (Questions $15-18$ Appenix A).

Among the four opportunities to obtain Be Bear Aware information, the website was the least likely source of information among campers to be accessed for the information with just over half of respondents indicating they visited the park's website while planning their visit to GRTE (see Table 7). And of those campers who accessed the website only half $(52 \%)$ said they read material on recreation in bear country. Interestingly $16 \%$ of campers said they did not notice the Be Bear Aware information on the website (see Appendix A, Question 15a).

Table 7. Source of Be Bear Aware Information by percentage

\begin{tabular}{|c|c|c|c|c|c|c|}
\hline \multirow[b]{2}{*}{ 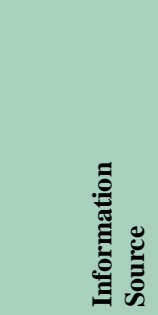 } & \multicolumn{2}{|c|}{ Campers } & \multicolumn{2}{|c|}{ Picnickers } & \multicolumn{2}{|c|}{ All } \\
\hline & 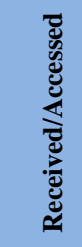 & 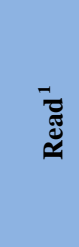 & 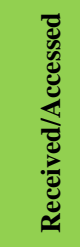 & 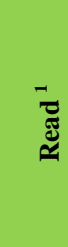 & 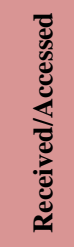 & 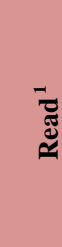 \\
\hline $\begin{array}{l}\text { Campground } \\
\text { /picnic } \\
\text { entrance* }\end{array}$ & 77.7 & 80.8 & 10. & 85.7 & 70.4 & 80.9 \\
\hline $\begin{array}{l}\text { Park } \\
\text { entrance* }\end{array}$ & 72.5 & 82.9 & 60.6 & 64.1 & 71.3 & 81.2 \\
\hline $\begin{array}{l}\text { Park } \\
\text { Personnel* }\end{array}$ & 57.6 & -- & 21.9 & -- & 53.8 & -- \\
\hline Website & 54.4 & 51.6 & 48.5 & 35.5 & 53.8 & 50.0 \\
\hline
\end{tabular}

The results for picnickers in Table 7 highlight the issue of dissimilar exposure to Be Bear Aware information. Among picnickers, receiving information at the entrance to the picnic site was the least likely mode for obtaining information (10.8\%), while it was the most likely venue for campers (77.7\%). Talking with park personnel was the second least likely mode for obtaining information $(22 \%)$ for picnickers, while for campers $57.6 \%$ received information in that manner.

More importantly, picnickers were less likely to receive Be Bear Aware information from any source compared to the campers. While picnickers are somewhat more likely to be from the local area, only $2.1 \%$ of all those interviewed were in fact living nearby. Hence picnickers as well as campers are coming into the area, without the benefit of local news stories about bear country.

Of those who responded yes to having received a spoken explanation about recreating responsibly in bear country, an overwhelming $77 \%$ of campers indicated this conversation occurred during campground registration (Table 8). The remaining choices on the survey received around 10 percent or less affirmative responses. Campground registration appears to be the best opportunity to verbally communicate to campers about the importance of proper food storage while in the park. Campground registration was also the highest source among picnickers for receiving a verbal explanation but only a third $(37 \%)$ indicated that this is where the conversation took place.

Table 8. Source of Verbal Explanation about Recreating Safely in Bear Country ${ }^{1}$

\begin{tabular}{|l|c|c|c|}
\hline $\begin{array}{l}\text { Source of Verbal } \\
\text { Explanation }\end{array}$ & Campers & Picnickers & All \\
\hline $\begin{array}{l}\text { Campground } \\
\text { registration* }\end{array}$ & $77.2 \%$ & $37.5 \%$ & $75.5 \%$ \\
\hline $\begin{array}{l}\text { Campground host } \\
\text { on patrol }\end{array}$ & $10.7 \%$ & $12.5 \%$ & $10.7 \%$ \\
\hline Other* & $9.5 \%$ & $25.0 \%$ & $10.2 \%$ \\
\hline Ranger on patrol & $9.5 \%$ & $12.5 \%$ & $9.6 \%$ \\
\hline Visitor center & $8.9 \%$ & $18.8 \%$ & $9.4 \%$ \\
\hline Campfire program & $6.3 \%$ & $6.3 \%$ & $6.3 \%$ \\
\hline
\end{tabular}

Total percentages are greater than 100 because visitors could select more than one answer choice.

${ }^{*}$ Chi-square test: $p<.001$

Interestingly, among the "other" sources of bear information were ferry captains, and boat captains. While several people mentioned other parks as the source of the information on bears (e.g. Yellowstone, Glacier), at least eight visitors mentioned the boat captains on Jenny Lake or the Snake river. This suggests that concessionaires may usefully be brought into the Be Bear Aware program.

Among campers, the number of prior visits to the park was the only trip characteristic that showed a significant difference in accessing Be Bear Aware information. Accessing the website was significantly lower among those who had visited the park two or more times in the last 24 months $(38 \%)$ compared to those who visited only once in the same time period $(64 \%)$ or for whom it was their first visit (55\%) (Figure 1). Similarly, information provided at campground registration was read significantly more often by first time ever visitors $(85 \%)$ and for whom it was their first visit in the past 24 months $(81 \%)$ compared to visitors who visited more often $(70 \%)$ (Figure 2). 


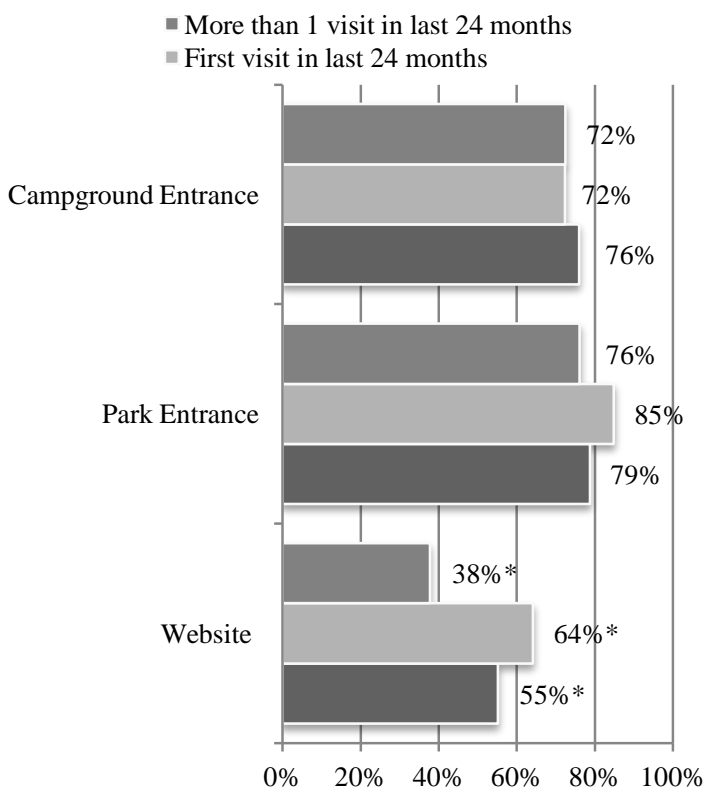

${ }^{*}$ Chi-square test: $p<.05 \quad$ Material received (\%)

Figure 1. Be Bear Aware Information Accessed by Number of Prior Visits

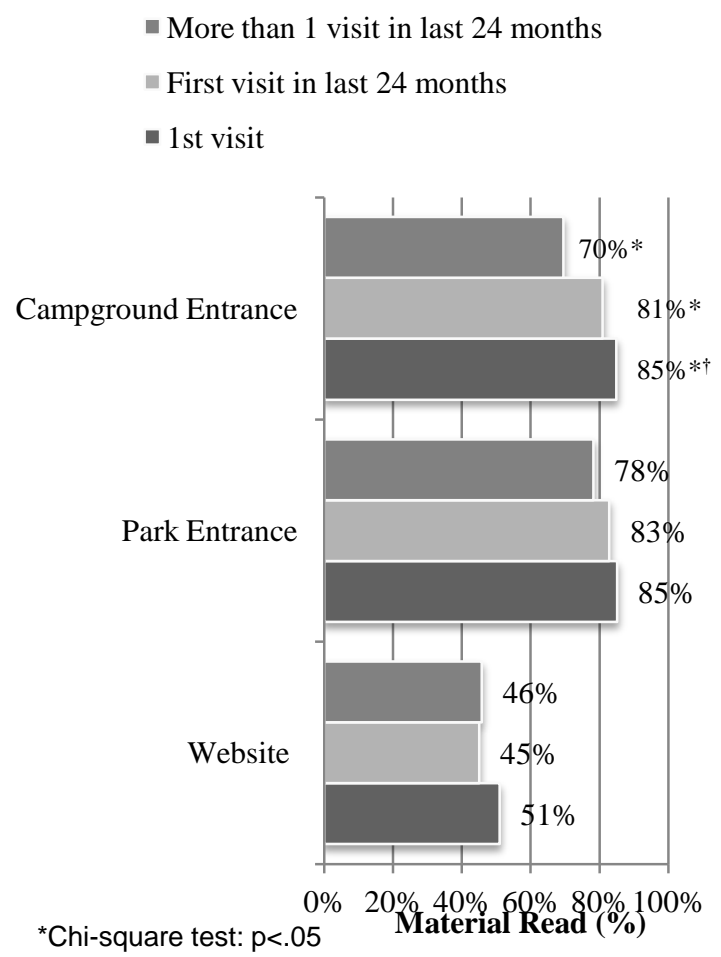

Figure 2. Be Bear Aware Information Read by Number of Prior Visits

\section{Comprehension of Be Bear Aware Information}

We tested for understanding of the park's rules on proper food storage by reading a list of items and asking survey respondents if according to park information sources the item could be kept in a tent overnight (Question 13 Appendix A; Table 9). The list of items was generated directly from the park's "Be Bear Aware! Food \& Odors Attract Bears" yellow plastic sign, which was stapled to every picnic table in the park.

Nearly half (49\%) of the campers gave the correct answer of "none of the above." Over a third of campers (37\%) believed it was okay to keep a water bottle in the tent overnight. Of greatest concern to the park would be number of campers responding "yes" to clean dishes, canned drinks, toiletries, and cook stove. These items, if stored in a tent overnight, pose a much greater risk of attracting a bear to the campground and particular tent. Choices that included food - any food in a cooler, uncooked food, snacks, pet food, and pet food bowls were given an affirmative answer by a small fraction (less than 2\%) of campers. To better understand these results we conducted additional analysis of the data that identified latent subgroups of campers based on their responses to Question 13.

Table 9. Knowledge of GRTE's Food Storage Policy ${ }^{1}$

\begin{tabular}{|l|c|c|c|}
\hline \multirow{2}{*}{ Items } & \multicolumn{3}{|c|}{$\begin{array}{c}\text { Percent Saying "Yes" to Storing in } \\
\text { a Tent Overnight }\end{array}$} \\
\cline { 2 - 4 } & Campers & Picnickers & All \\
\hline $\begin{array}{l}\text { None of the } \\
\text { above* }\end{array}$ & $48.6 \%$ & $28.4 \%$ & $46.4 \%$ \\
\hline Water bottles* & $36.9 \%$ & $64.2 \%$ & $39.8 \%$ \\
\hline Clean dishes & $28.1 \%$ & $38.8 \%$ & $29.3 \%$ \\
\hline $\begin{array}{l}\text { Canned drinks } \\
\text { (unopened)* }\end{array}$ & $23.7 \%$ & $40.3 \%$ & $25.4 \%$ \\
\hline Toiletries* & $10.9 \%$ & $20.9 \%$ & $12.0 \%$ \\
\hline Cook stove & $4.7 \%$ & $3.0 \%$ & $4.5 \%$ \\
\hline $\begin{array}{l}\text { Any food in a } \\
\text { cooler }\end{array}$ & $1.8 \%$ & $1.5 \%$ & $1.8 \%$ \\
\hline $\begin{array}{l}\text { Uncooked food } \\
\text { in its original } \\
\text { wrapping }\end{array}$ & $1.6 \%$ & $1.5 \%$ & $1.6 \%$ \\
\hline Pet food bowls & $1.4 \%$ & $0.0 \%$ & $1.3 \%$ \\
\hline Snacks & $0.9 \%$ & $3.0 \%$ & $1.1 \%$ \\
\hline Dry dog food & $0.4 \%$ & $0.0 \%$ & $0.3 \%$ \\
\hline
\end{tabular}

Total percentages are greater than 100 because visitors could select more than one answer choice.

${ }^{*}$ Chi-square test: $p<.05$ 
Picnickers tended to respond differently than campers to the question. Significantly fewer picnickers answered the question correctly and significantly more selected water bottles, canned drinks (unopened), and toiletries as being allowed in the tent overnight. What this suggests is that more visitors to the campgrounds are getting the bear aware message than is true of picnickers. While park officials must decide how much time they devote to education, the fact that pcinickers do not receive as much information may not be as critical as the fact that a significant percentage of campers still believe they can keep dishes, canned drinks, and toiletries in their tents overnight. Since the time in the park is much longer for campers than for picnickers, and since items in tents may be left unattended during the day, the risk for bear attraction is much greater in the campground than in the picnic area.

Next we evaluated campers' answers to the food storage question after controlling for where they read, heard or saw Be Bear Aware information. The only source of information that resulted in a significantly higher percentage of campers providing the correct answer was whether or not the camper had seen the sign "Be Bear Aware! Food \& Odors Attract Bears" (Figure 3). This result suggests an association between seeing the sign and knowing the park's food storage policy. We also evaluated the food storage question in light of different trip characteristics. We found that knowledge of the park's food storage policy was significantly greater among those campers who were staying in a tent compared to those who were not staying in a tent (Figure 4). Furthermore, the number of visits to GRTE was associated with knowledge on proper food storage. Fewer wrong answers were recorded among those campers who visited the park two or more times in the last 24 months compared to those campers for whom it was their first visit in the last 24 months or their first visit ever to the park (Figure 5).

Since the Be Bear Aware Program had begun two years earlier, the visitors who reported more than one visit to the park, were more likely to have been exposed to the messages more often. This is another indicator that the Be Bear Aware message is being perceived by visitors, and that it may take more than one exposure to correct behavior.

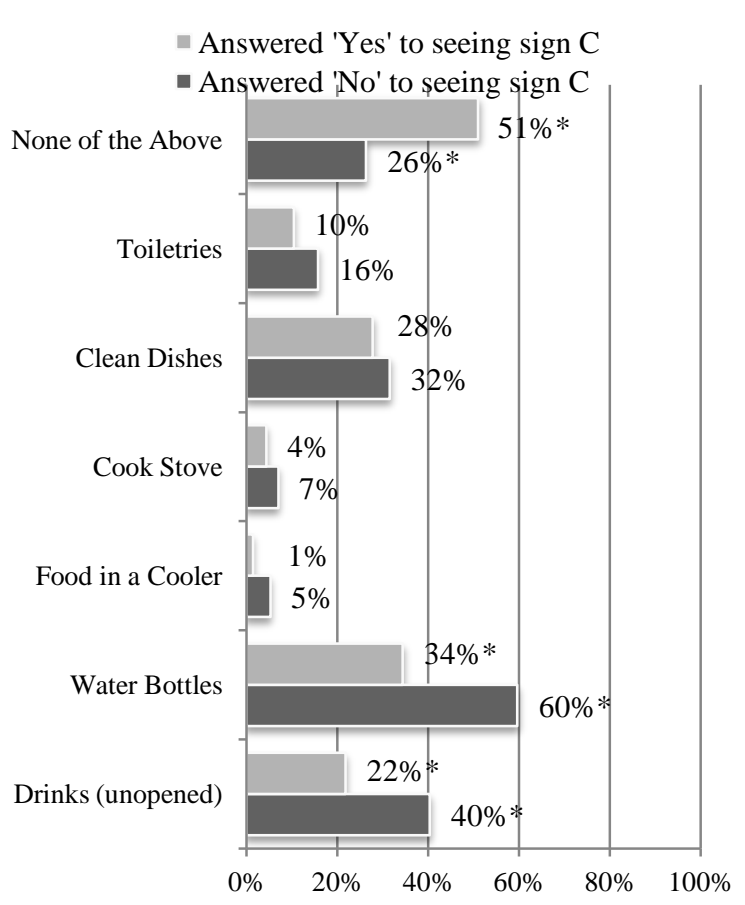

${ }^{*}$ Chi-square test: $p<.05$

Answered Yes (\%)

Figure 3. Knowledge of Food Storage Policy by Sign Sighting

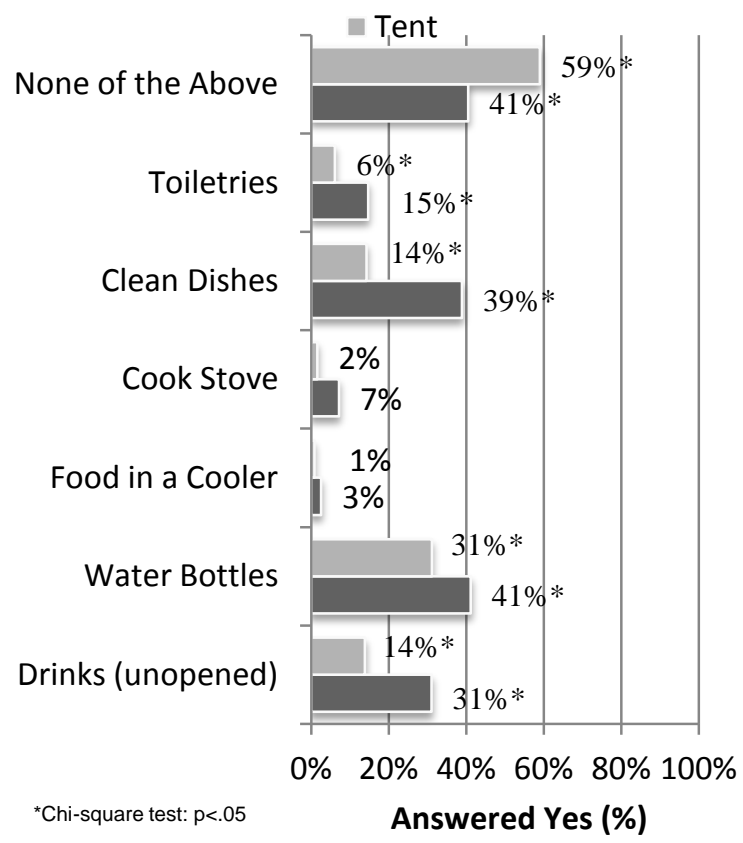

Figure 4. Knowledge of Food Storage Policy by Overnight Accommodation 


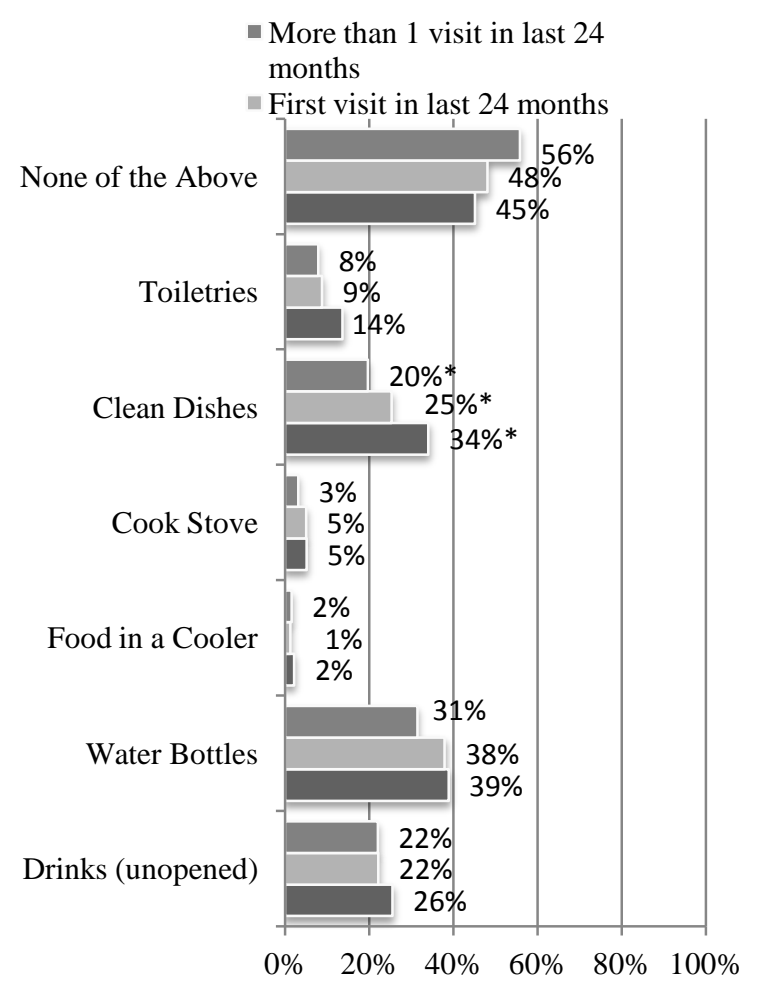

${ }^{*}$ Chi-square test: $p<.05$

Figure 5. Knowledge of Food Storage Policy by Number of Prior Visits

\section{Visitor Behavior While in Bear Country}

To assess visitors' behavior while in bear country we asked a series of questions pertaining to food storage and recreation (Question 14 a-f Appendix A). Survey participants were asked to respond to the questions on a scale from strongly agree to strongly disagree. Table 10 summarizes the results. The percentage of respondents' providing the correct answer was slightly higher for questions that included storage of food or garbage compared to questions on storage of personal products or leaving the car windows open for ventilation. These results suggest that nearly all campers and picnickers were storing food and trash in accordance with the park's policies. However, a slightly lower percentage said they were storing non-food items such as wash tubs, dishes and personal products correctly, with a larger gap on this item between the campers and the picnickers.
Table 10. Food Storage Behavior by percentage

\begin{tabular}{|c|c|c|c|c|c|c|}
\hline \multirow[b]{2}{*}{ Statement $^{1}$} & \multicolumn{2}{|c|}{ ڤัँ } & \multicolumn{2}{|c|}{ 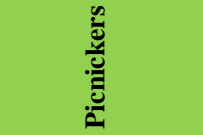 } & \multicolumn{2}{|c|}{$\bar{z}$} \\
\hline & $\underset{\alpha}{20}$ & 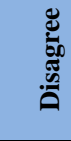 & 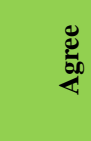 & 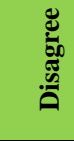 & 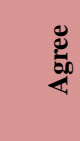 & 莺 \\
\hline $\begin{array}{l}\text { Garbage must } \\
\text { be stored in } \\
\text { the same } \\
\text { manner as } \\
\text { food. }\end{array}$ & 100.0 & 0.0 & 100.0 & 0.0 & 100.0 & 0.0 \\
\hline $\begin{array}{l}\text { I always store } \\
\text { my food in a } \\
\text { bear box or the } \\
\text { car when not } \\
\text { in use. }\end{array}$ & 98.7 & 0.9 & 95.5 & 4.5 & 98.5 & 1.3 \\
\hline $\begin{array}{l}\text { I still need to } \\
\text { be concerned } \\
\text { about food } \\
\text { smells when } \\
\text { out on a hike. }\end{array}$ & 98.7 & 0.9 & 100.0 & 0.0 & 98.9 & 0.8 \\
\hline $\begin{array}{l}\text { Wash tubs, } \\
\text { basins \& } \\
\text { dishes must be } \\
\text { stored in the } \\
\text { same manner } \\
\text { as food. }{ }^{\dagger}\end{array}$ & 92.2 & 5.3 & 83.0 & 13.9 & 90.7 & 6.1 \\
\hline $\begin{array}{l}\text { Personal } \\
\text { products must } \\
\text { be stored in a } \\
\text { bear box or the } \\
\text { car. }\end{array}$ & 89.4 & 8.3 & 89.2 & 10.8 & 89.4 & 8.6 \\
\hline $\begin{array}{l}\text { Car windows } \\
\text { cannot be left } \\
\text { open even an } \\
\text { inch for } \\
\text { ventilation. }\end{array}$ & 87.6 & 11.0 & 87.5 & 9.4 & 87.6 & $\begin{array}{c}10 . \\
8\end{array}$ \\
\hline
\end{tabular}

Agree equals the combined results for "strongly agree" and "agree somewhat."

Disagree equals the combined results for "strongly disagree" and "disagree somewhat."

Neutral responses are not shown (see Appendix A, Tables 17-22).

${ }^{1}$ See Appendix A, questions 40-46 for exact wording of questions.

${ }^{*}$ Chi-square test: $p<.05$

${ }^{\dagger}$ Linear-by-linear association test $p<.05$

\section{Does the Information Transcend the Campground?}

To find out if information on how to recreate safely and responsibly while in the park was reaching visitors, we asked a series of questions related to this topic (Questions 21a-f Appendix A). The questions were generated directly from material presented in the park's paper, the Teewinot. Campers and picnickers overwhelmingly agreed with the statement that black bears are a threat to humans, bears move around day and night, grizzly bears live in GRTE, and running away from a bear can cause an aggressive response in the bear (Table 11). 
Table 11. Knowledge of Recreating Safely While in Bear Country. Numbers are percentages of respondents

\begin{tabular}{|c|c|c|c|c|c|c|}
\hline \multirow[b]{2}{*}{ 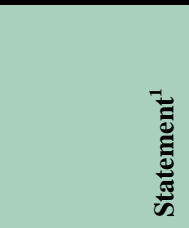 } & \multicolumn{2}{|c|}{ Campers } & \multicolumn{2}{|c|}{ Picnickers } & \multicolumn{2}{|c|}{ All } \\
\hline & 递 & 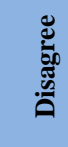 & 离 & 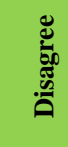 & 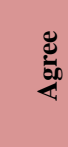 & 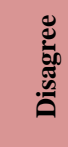 \\
\hline $\begin{array}{l}\text { Running away } \\
\text { from a bear can } \\
\text { cause an } \\
\text { aggressive } \\
\text { response }\end{array}$ & 98.9 & 0.7 & 97.0 & 3.0 & 98.7 & 0.9 \\
\hline $\begin{array}{l}\text { Bears move } \\
\text { around night \& } \\
\text { day }\end{array}$ & 98.2 & 1.6 & 100.0 & 0.0 & 98.3 & 1.5 \\
\hline $\begin{array}{l}\text { Grizzly bears } \\
\text { live in GRTE }\end{array}$ & 97.2 & 2.2 & 96.6 & 1.7 & 97.2 & 2.1 \\
\hline $\begin{array}{l}\text { Black bears are } \\
\text { a threat to } \\
\text { humans }^{\dagger}\end{array}$ & 95.9 & 3.1 & 100.0 & 0.0 & 95.2 & 2.8 \\
\hline $\begin{array}{l}\text { Dropping food } \\
\text { or a backpack } \\
\text { is not a good } \\
\text { strategy when } \\
\text { a bear } \\
\text { approaches }\end{array}$ & 82.1 & 15.7 & 77.5 & 17.1 & 81.7 & 16.0 \\
\hline $\begin{array}{l}\text { Bears are } \\
\text { unpredictable }\end{array}$ & 81.3 & 13.4 & 89.5 & 3.2 & 82.2 & 12.3 \\
\hline
\end{tabular}

Agree equals the combined results for "strongly agree" and "agree somewhat."

Disagree equals the combined results for "strongly disagree" and "disagree somewhat."

Neutral responses are not shown (see Appendix A, Tables 40-46).

${ }^{1}$ See Appendix A, Tables $40-46$ for exact wording of questions.

${ }^{\dagger}$ Linear-by-linear association test $p<.05$

Two questions for which campers and picnickers did not perform as well included dropping food or a backpack to distract a bear $(82.1 \%$ for campers and $77.5 \%$ for picnickers, agreed that this was not a good idea) and agreeing that bears are unpredictable $(81.3 \%$ for campers and $89.5 \%$ for picnickers). The answers to these two questions suggest that as park visitors move away from the organized sites (picnic grounds and campgrounds) they may rely more on their own beliefs. For nearly $19 \%$ of the campers to suggest that they believe that bears are predictable is a cautionary warning for the Be Bear Aware program leaders.

\section{Most Important Bear Safety Information to Visitors}

Campers and picnickers indicated that GRTE material, which includes signs, handouts and the Teewinot, was the most important source of information in educating them about proper food storage and recreating safely in bear country (Table 12). A significant percentage of the visitors, however, reported that their own experience was the most important source of information. Indeed so important was "own personal experience" that this category was captured from the open-ended comments for "Of all the information you have received on safety in bear country, which source had the greatest impression?"

Table 12. Most Important Source of Bear Safety Information

\begin{tabular}{|l|c|c|c|}
\hline Information Source & Campers & Picnickers & All \\
\hline GRTE material $^{1}$ & $43.6 \%$ & $43.3 \%$ & $43.7 \%$ \\
\hline Verbal $^{2}$ & $27.3 \%$ & $17.9 \%$ & $26.3 \%$ \\
\hline Personal experience & $14.6 \%$ & $13.4 \%$ & $14.4 \%$ \\
\hline $\begin{array}{l}\text { Material from other } \\
\text { parks }\end{array}$ & $6.0 \%$ & $12.0 \%$ & $6.6 \%$ \\
\hline Other $^{3}$ & $8.5 \%$ & $13.5 \%$ & $9.0 \%$ \\
\hline
\end{tabular}

GRTE material equals the combined results for "Grand Teton website" and "Other Grand Teton material."

${ }^{2}$ Verbal equals the combined results for "talking with park personnel" and "talking with friends or family members."

${ }^{3}$ Other equals the combined results for "TV programs", "news" and "other material"

\section{Identification of Camper Subgroups}

The last analysis we provide here in the Latent Class Analysis mentioned earlier. Again, this analysis helps to group similar types together (such as those campers who produced more correct answers on the food storage questions) revealed a four-group typology based on campers' responses to survey questions designed to assesses their knowledge of the park's policy on food storage. Table 13 summarizes the conditional probabilities of answering "yes" to a series of items presented in the survey question: "According to the park, which of the following can be kept in a tent overnight?" For instance, a camper in Group 3 has a $61 \%$ chance of saying it's okay to keep a water bottle in the tent overnight. The last row in Table 13 presents the size of each group.

To assist the reader in understanding the LCA results, we developed the following descriptions and corresponding labels for each group (Table 14). We interpreted items with conditional probabilities of around 0.2 as being sufficiently low that these items were not included in the group descriptions and labels. Nearly half $(49 \%)$ of the campers interviewed answered the question correctly (the "A+ visitor" group) and $13 \%$ indicated water bottles were ok (the "water bottle" group). The "non-food items" group (Group \#3) tended to select unopened canned drinks, water bottles and clean dishes as being allowed in a tent overnight and comprised just over a third of campers $(35 \%)$. Fortunately for the park, only $3 \%$ of campers - the "unaware" group - had no idea as to what can be stored in a tent overnight. 
Table 13. Latent Class Analysis Results

\begin{tabular}{|l|c|c|c|c|}
\hline \multirow{2}{*}{\begin{tabular}{l}
\multirow{2}{*}{ Items } \\
None of the
\end{tabular}} & \multicolumn{3}{|c|}{$\begin{array}{c}\text { Conditional probability of answering } \\
\text { "yes" to the item being stored in a tent } \\
\text { overnight }\end{array}$} \\
\cline { 2 - 5 } & \multicolumn{4}{|c|}{ Groups } \\
\cline { 2 - 5 } & $\mathbf{1}$ & $\mathbf{2}$ & $\mathbf{3}$ & $\mathbf{4}$ \\
\hline Water bottles & 1.00 & 0.00 & 0.00 & 0.01 \\
\hline Clean dishes & 0.00 & 1.00 & 0.61 & 0.86 \\
\hline $\begin{array}{l}\text { Canned drinks } \\
\text { unopened) }\end{array}$ & 0.00 & 0.01 & 0.74 & 0.90 \\
\hline Toiletries & 0.00 & 0.04 & 0.51 & 0.97 \\
\hline Cook stove & 0.00 & 0.03 & 0.08 & 0.98 \\
\hline $\begin{array}{l}\text { Any food in a } \\
\text { cooler }\end{array}$ & 0.00 & 0.04 & 0.01 & 0.27 \\
\hline $\begin{array}{l}\text { Uncooked food } \\
\text { in its original } \\
\text { wrapping }\end{array}$ & 0.00 & 0.00 & 0.01 & 0.39 \\
\hline Pet food bowls & 0.00 & 0.02 & 0.01 & 0.28 \\
\hline Snacks & 0.00 & 0.00 & 0.00 & 0.33 \\
\hline Dry dog food & 0.00 & 0.00 & 0.00 & 0.07 \\
\hline Group size & $\mathbf{4 9 \%}$ & $\mathbf{1 3 \%}$ & $\mathbf{3 5 \%}$ & $\mathbf{3 \%}$ \\
\hline
\end{tabular}

Another way to read this table is to be assured that $62 \%$ of those individuals interviewed knew the park rules about food storage, with only minor deviations. However, $38 \%$ of the park campers had some significantly different answers on proper food storage (especially water bottles, canned drinks, clean dishes, and toiletries). This suggests that the park has produced an appropriately drawn program to group these somewhat disparate items together.

Table 14. Latent Class Analysis Subgroup Descriptions

\begin{tabular}{|c|c|c|c|}
\hline $\begin{array}{c}\text { LCA } \\
\text { Group }\end{array}$ & $\begin{array}{c}\text { Bear } \\
\text { Aware } \\
\text { Level }\end{array}$ & Label & Description \\
\hline Group 1 & \multirow[t]{2}{*}{ Strong } & $A+$ visitor & $\begin{array}{l}\text { Provided the } \\
\text { correct answer to } \\
\text { the question - } \\
\text { none of the above. }\end{array}$ \\
\hline Group 2 & & Water bottles & $\begin{array}{l}\text { Said yes to water } \\
\text { bottles. }\end{array}$ \\
\hline Group 3 & $\downarrow$ & $\begin{array}{l}\text { Non-food } \\
\text { items }\end{array}$ & $\begin{array}{l}\text { Said yes to non- } \\
\text { food items - } \\
\text { unopened canned } \\
\text { drinks, water } \\
\text { bottles, clean } \\
\text { dishes. }\end{array}$ \\
\hline Group 4 & Weak & Unaware & $\begin{array}{l}\text { Had very little } \\
\text { awareness of the } \\
\text { park's food } \\
\text { storage policy. }\end{array}$ \\
\hline
\end{tabular}

In our period of questionnaire development, we are reminded how many times survey volunteers mentioned pictures at various sites as drawing them into reading the material on bears. Perhaps more of these pictures with the signpost ("it's only a bar of soap," etc.) could be useful tools for addressing this third of the park campers.

\section{$\uparrow \quad$ SUMMARY}

WYSAC collected information on the visibility of Be Bear Aware signs, access to and use of Be Bear Aware information, visitor knowledge of GRTE's food storage policy and safe recreation while in bear country, and self-reported behavior of visitors while in the park. The purpose of collecting this information was to evaluate the public education and information component of the Be Bear Aware program and inform park managers on the effectiveness of this part of the program.

The materials created for Be Bear Aware were being seen, accessed, and understood by a majority of campers and picnickers visiting the park during the summer of 2010. We did find areas where the park message is not penetrating the visitor experience.

\section{Storage of Non-Food Items}

Nearly all campers and picnickers (over $98 \%$ combined) indicated they store their food and garbage in a vehicle, a bear box, or the dumpster. The percentage of visitors who said they stored their nonfood (but attractive bear items) in the same manner as food was 6 to 10 percentage points lower. Furthermore, we found that about a third $(35 \%)$ of campers incorrectly selected non-food items (i.e., water bottles, canned drinks, clean dishes) as being allowed in a tent overnight. Fortunately only $3 \%$ of campers did not know the park's food storage policy when asked what can be stored in a tent overnight. A review of items for which Dear Camper citations were issued during the summer of 2010 might corroborate this finding. We believe these findings suggest that at most a third of visitors do not know or do not follow the park's policy regarding storage of non-food items.

\section{Be Bear Aware Beyond the Campground \& Picnic Areas}

A surprising number of campers and picnickers (16\% combined) indicated that dropping food or a backpack was a good strategy for distracting a bear if one should approach. Strategies for what to do should a visitor encounter a bear are clearly laid out in the park's newspaper, the Teewinot. 
Dropping food or a backpack is not recommended. Although significantly fewer picnickers said they received $\mathrm{Be}$ Bear Aware information at the park entrance than campers (and even fewer read the information), the percentage of each group agreeing with this strategy was the same. The Teewinot also clearly states that a bear's behavior cannot be predicted. Yet $13 \%$ of campers said they had read enough about bears to think they could predict when a bear would turn aggressive.

\section{Educating Park Service Providers}

Although we have little information on this, the answers to open-ended questions suggest that many park visitors get information from sources other than those enumerated in our questionnaire. Especially noted were service providers on boats in both lakes and rivers. This source of information could also be a good way to reach the camper or picnicker who has not yet read the Teewinot, or received Be Bear Aware information.

Of course, some people come to the park wanting an experience with a bear. As one woman said in our pre-testing," I want a bear to come into the campground." With sentiments such as these, GRTE will never get $100 \%$ compliance on food storage, but there is room to reach more visitors.

\section{$\downarrow$ ACKNOWLEDGEMENTS}

We would like to thank Kate Wilmot and the volunteers with the Wildlife Brigade for their assistance in fielding the survey. We would also like to thank Sue Consolo-Murphy for her input and support of the project. Jim Gramann (Acting Director, National Park Service Social Science Division) also guided this proposal through the review process of the Office of Management and Budget. This research was funded by a UW-NPS research grant awarded to P. A. Taylor and N. M. Nelson and GRTE's Bear Aware Project. Funding was also secured through the EPSCoR program at the University of Wyoming (A. Rieser and P. Taylor) to provide support for the study of the sampling frame. This manuscript is a contribution to the University of Wyoming/National Park Service Research Station.

\section{$\uparrow \quad$ Literature Cited}

Grand Teton National Park. 2007. 2007 Wildlife Management: Human-Bear Conflicts. Retrieved December 3, 2009, from http://www.nps.gov/grte/planyourvisit/uploa d/FINAL_2007_humanbear_conflicts_brief.pdf

Lackey BK. 2002. Empirical And Theoretical Analysis Of Communication Focused On Human-Black Bear Conflicts In Yosemite National Park. University of Idaho: Doctoral Dissertation.

Nelson NM, Taylor PA, Rieser A. 2009. Evaluation of Grand Teton National Park's "Be Bear Aware" Message to Visitors. UW NPS Research Station Annual Report 2009. Laramie, WY: University of Wyoming.

Nelson NM, Taylor PA, Hopkins T, Rieser A. 2011. Evaluation of Grand Teton National Park's "Be Bear Aware" Message to Visitors, WYSAC Technical Report No. SRC-1102. Laramie, WY: Wyoming Survey \& Analysis Center, University of Wyoming.

Wright G. 1992. Wildlife Research and Management in the National Parks. Urbana: University of Illinois Press. 
Appendix A: Be Bear Aware Questionnaire

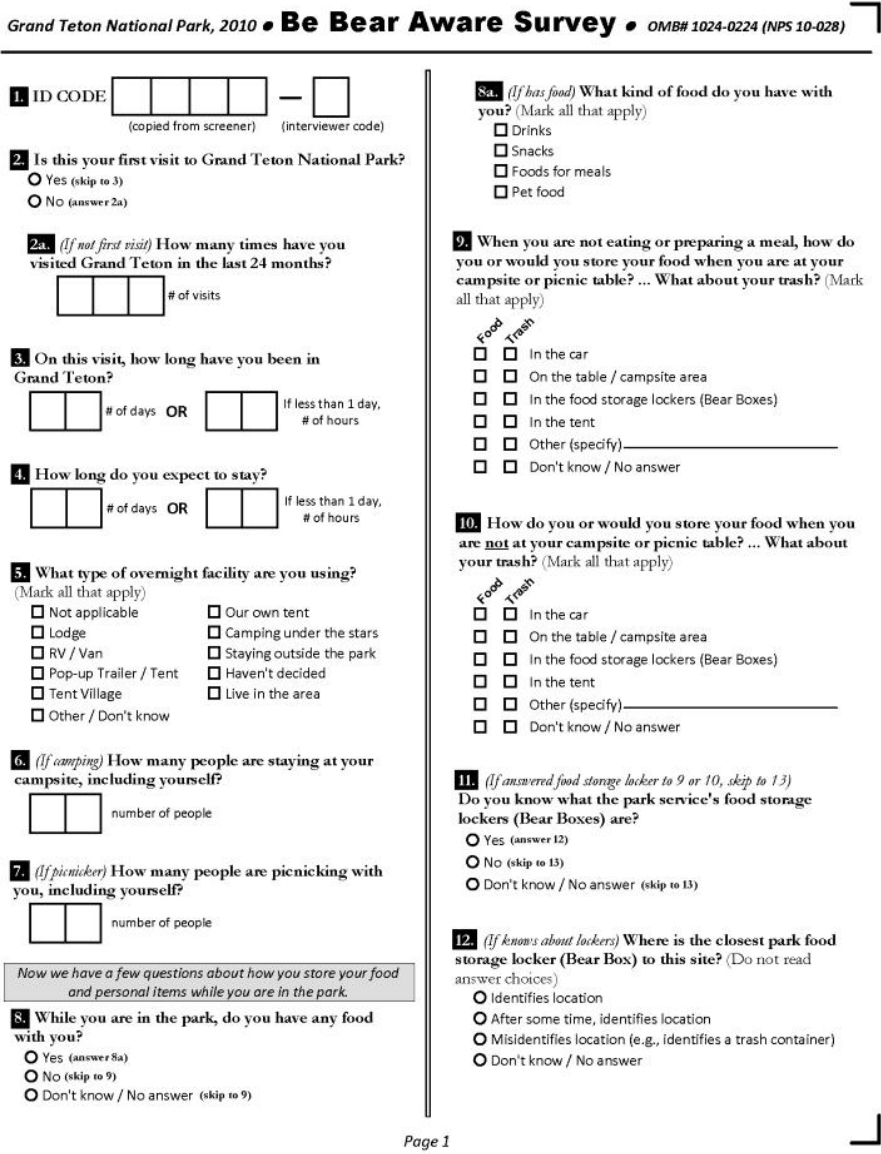

$\Gamma$

13. Whether you are in a tent or an RV or just picnicking, we want to know what you think the park's policy is on food rage. According to the park, which of the following can be kept in a tent overnight? (Mark as many as affirmed) 口Snacks $\square$ Any food in a cooler Uncooked food in its original wrapping/packaging Drydog food $\quad \square$ cook stove $\quad$ Toiletries $\begin{array}{lll}\text { Q Canned drinks (unopened) } & \text { Q Pet food bowls } & \text { QNone of the above } \\ \square \text { Water bottles } & \square \text { Clean dishes } & \text { QNo answer }\end{array}$

14. This is the last set of food storage questions. Just tell me whether you strongly agree, agree somewhat, are
neutral, disagree somewhat, strongly disagree or don't know for the following statements.

\begin{tabular}{|l|c|c|c|c|c|c|}
\hline $\begin{array}{l}\text { a. I always store my food when not in use in a bear resistant } \\
\text { container or in the car. }\end{array}$ & 0 & 0 & 0 & 0 & 0 & 0 \\
\hline $\begin{array}{l}\text { b. Garbage must be stored in the same manner as food, or } \\
\text { placed in bear-resistant trashcans. }\end{array}$ & 0 & 0 & 0 & 0 & 0 & 0 \\
\hline $\begin{array}{l}\text { c. Personal products such as soap, deodonant, toothpaste, } \\
\text { sunscreen, and bug spryy do not have to be stored in bear } \\
\text { safety contuiners or in the car. }\end{array}$ & 0 & 0 & 0 & 0 & 0 & 0 \\
\hline $\begin{array}{l}\text { d. Wash tubs, basins, and dishes must be stored in the same } \\
\text { manner as food. }\end{array}$ & 0 & 0 & 0 & 0 & 0 & 0 \\
\hline $\begin{array}{l}\text { e. When I store food in the car, I can leave the windows } \\
\text { cracked one inch or less for ventilation. }\end{array}$ & 0 & 0 & 0 & 0 & 0 & 0 \\
\hline $\begin{array}{l}\text { f. When out on a hike, I still need to be concemed about } \\
\text { smells from any food I carry. }\end{array}$ & 0 & 0 & 0 & 0 & 0 & 0 \\
\hline
\end{tabular}

Now I want to ask you some questions about the park's Be Bear Aware program. Grand Teton National Park has been tying to educate visitors about safe and responsible recreation in bear country. We want to know how mutch pur trying to educate visitors about safe and responsible recreation in bear country. We want to know how much you might
know about this program and its message. There are no right or wrong answers; the best answers tell us what you really remember.

15. When planning your trip to the park, did you access the website for Grand Teton? O Yes, I accessed the Grand Teton website (answer 15a) ONo (skip to 16)

(If accessed the vecbite) Did you read any of the information on proper food storage on the websie? Y Y Didn't notice it on the site

Did you receive any printed material when you entered the park regarding safe and responsible recreation in bear country?

O No, lalready had copies of the information (skip to 1 )

Don't know / No answer (skip to 17 )

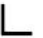

Page 2 
Appendix A: Be Bear Aware Questionnaire (Continued)

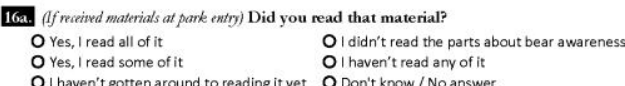

18. Did you receive a spoken explanation about the importance of safe and responsible recreation in bear country? O Yes (answer 18a) O No (skip to 19)

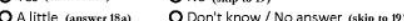

18. (ff receind spoken explanation) Where did you receive that explanation? (Mark all that apply) In a campfire program $\quad$ From a campground host/concessionaire on patro At camperound registration $\quad$ Oother (specify) G From a ranger on patrol $\quad$ Don't know / No answer $\square$ At the visitor center

19. Lots of people have told us that they get information about safety in bear country from a variety of sources. county, which one had the greatest impression? OTV programs O Talking with park personne

O Grand Teton website Talking with friends or family members

There are many different Bear Aware signs you might have seen on this trip. Not everybody sees ever sign, so as I show you a sign, please let me know whether or not you remember seeing this sign on this trip to Grand Teton, and if you have seen it where it was and how many times.

\begin{tabular}{|l|c|c|c|c|c|c|c||}
\hline a. Footprint - Be Bear Aware & 0 & 0 & 0 & & \\
\hline b. Waming - BEAR Frequenting Area & 0 & 0 & 0 & & \\
\hline c. Be Bear Aware - Food and Odors Attract Bears & 0 & 0 & 0 & & \\
\hline d. You Can Help Save a Bear & 0 & 0 & 0 & & \\
\hline c. Warning - Trail closed due to Bear activity & 0 & 0 & 0 & & \\
\hline f. Be Bear Aware - Food Stonage Required & 0 & 0 & 0 & & \\
\hline
\end{tabular}

21. Now I have a few statements about safery in bear country. Please tell me whether you strongly agree, agr disagree or don't know with the following stateseng.

\begin{tabular}{|l|c|c|c|c|c|c|c|}
\hline $\begin{array}{l}\text { a. I have read so much about bears that I think that I am } \\
\text { able to predict when a bear will tum aggressive. }\end{array}$ & 0 & 0 & 0 & 0 & 0 & 0 \\
\hline b. Black bears are not a threat to humans. & 0 & 0 & 0 & 0 & 0 & 0 \\
\hline $\begin{array}{l}\text { c. If a bear approaches a person, a good strategy to distract } \\
\text { the bear is dropping food or a backpack. }\end{array}$ & 0 & 0 & 0 & 0 & 0 & 0 \\
\hline d. Grizzly bears live in Grand Teton National Park. & 0 & 0 & 0 & 0 & 0 & 0 \\
\hline $\begin{array}{l}\text { e. Running away from a bear can cause an aggressive } \\
\text { response in the bear. }\end{array}$ & 0 & 0 & 0 & 0 & 0 & 0 \\
\hline $\begin{array}{l}\text { f. It is unlikely that a bear will enter this campground or } \\
\text { picnic area while people are here. }\end{array}$ & 0 & 0 & 0 & 0 & 0 & 0 \\
\hline g. Bears only move around at night. & 0 & 0 & 0 & 0 & 0 & 0 \\
\hline
\end{tabular}

22. 22. How
freely?

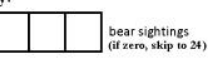

23. How many times have you seen a bear in Gran Teton National Park? \begin{tabular}{|l|l|l|}
\hline & & \\
\hline
\end{tabular}

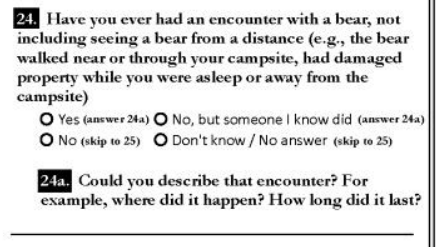
example, where did it happen? How long did it las

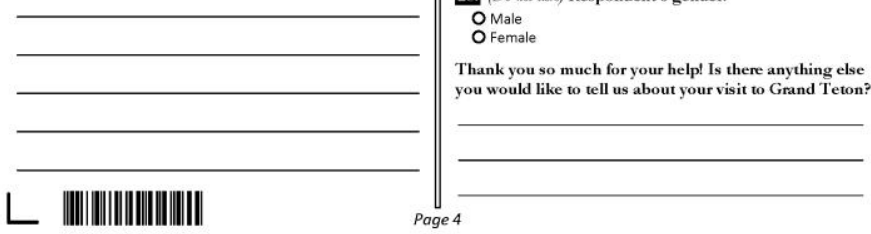

Probe then record whether experience mus more pesititu or negatine) How would you characterize the
For example, were you scared or excited?

I have a few questions to ask about you, for sampling purposes.

25. In what year were you born?

\begin{tabular}{|l|l|l|l|}
\hline 1 & 9 & & \\
\hline
\end{tabular}

26. What is the highest level of education you hav Ompleted?

O High school graduate or GED

O Some college or technical schoo

O Eachelor's degree

27. In what state or country do you live?

(Da not ack) Respondent's gender OFemale

Thank you so much for your help! Is there anything else 